\title{
Introduction to Special Series on Tools, Techniques, and Technologies for Promoting Organizational Learning
}

\author{
Shirley A. Becker \\ Computer Science \& Software Engineering \\ Florida Institute of Technology
}

\author{
becker@cs.fit.edu
}

\section{Learning Organizations}

Peter Senge (1990) and others working at the MIT Center for Organizational Learning have provided insight on the foundational components of a "learning" organization. They have defined organizational learning as occurring when members have a shared vision and work together to achieve common goals in order to produce results that are important to them. In today's technologically complex world, organizational learning offers a means of adaptation, survival, and long-term growth. (The MIT Center for Organizational Learning has published numerous articles on the concepts proposed in Senge's (1990) The Fifth Discipline. Refer to their web site (http://learning.mit.edu/) for more information.)

Much of the work on organizational learning has been based on work done by Argyis (1992), Handy (1995), and others in Organizational Development (OD). OD focuses on continuous improvements in an organization using interdisciplinary approaches and modern technologies (Larsen et al., 1996). Organizational learning concepts continue to expand upon OD in terms of promoting a cycle of learning and improvement at all levels in the organization.

Five technologies, system thinking, personal mastery, mental models, shared vision, and team learning, provide a basis for the pursuit of organizational learning (Refer to Senge (1990) for an in depth discussion of these technologies). These technologies are used to promote a learning cycle whereby organ-

Material published as part of this journal, either on-line or in print, is copyrighted by the publisher of Informing Science. Permission to make digital or paper copy of part or all of these works for personal or classroom use is granted without fee provided that the copies are not made or distributed for profit or commercial advantage AND that copies 1) bear this notice in full and 2) give the full citation on the first page. It is permissible to abstract these works so long as credit is given. To copy in all other cases or to republish or to post on a server or to redistribute to lists requires specific permission and payment of a fee. Contact Editor@inform.nu to request redistribution permission. izational members work together to continuously learn and improve. Individuals, teams, and the organization work together in establishing long-term goals. This is done by taking into account mental models or perceptions of the world, systems thinking in terms of interdependencies and relationships among people and processes, and personal mastery and learning capabilities for creativity, innovation, and adaptation, among other factors.

\section{Riding the Wave}

Learning organization concepts, tools, and technologies will continue to play a significant role in riding the increasingly turbulent wave of technological advances. The Internet, in particular, is having a major impact on the way organizations do business in a global marketplace. Our mental models regarding communication and information dissemination, product and service value, as well as many other aspects of the business world are changing due to Internet use at personal, team, and organizational levels.

The explosion of web-enabling technologies is changing our value perceptions of individuals and teams. Skilled technology workers are no longer considered liabilities but valuable assets. The development of high-performance teams is viewed as a long-term investment instead of a major expense. The gathering and dissemination of meaningful information (or knowledge) is being viewed as essential as organizations realize the benefits associated with a virtually endless supply of this valuable resource (Allee, 1999).

Organizations have also realized the potential for process improvement by implementing Deming's (1982) plan, do, check, and act feedback cycle (or variations of it). Today, organizations are promoting a learning environment by expanding upon this simple feedback process. Process improvement initiatives include the Capability Maturity Model (CMM) (Paulk, et al., 1995). The CMM offers improved capabilities in the application of software processes and practices that 
have resulted in productivity, quality, and time-to-market gains (Herbsleb, 1994).

Though we have come a long way in developing tools, techniques, and technologies to promote learning environments, there is still much to be done. This area of study becomes all the more urgent with the advancement of technology and the explosion in its use. Organizational survival will depend on adaptation to change associated with current and future technologies.

The objective of this special series is to share advancements in tools, techniques, and technologies to promote organizational learning. There are four articles in this series each of which discusses future opportunities for learning.

\section{Tools, Techniques, and Technologies}

From a technological perspective, organizations focused on learning understand the importance of knowledge management such that lessons learned and good practices are disseminated for ongoing improvement. Yet, there is little guidance available on the collection of good practices and lessons learned. The article entitled, "Organizational Learning Through the Collection of Lessons Learned," by Joseph Vandeville, focuses on addressing this need. The process infrastructure, used by an organization, is described in order to collect lessons learned that can be acted upon by the organization's process improvement program.

Effective knowledge management may be a difficult task as knowledge takes on various formats (verbal, written, and visual), may not be readily accessible, may be cryptic or incomplete, or its location unknown. What we need are more effective mechanisms for managing the wealth of information that becomes available to an organization. The article entitled, "Learning from the World Wide Web: Using Organizational Profiles in Information Searches," by Anthony Scime, describes an architecture for query construction and results refinement using experience and knowledge. Organizational knowledge, inclusive of previous queries, is used to design a Web query for effective searches. The organization's historical knowledge on source quality is used to assess the quality of the query results.

A third article by Peter Bednar, "A Contextual Integration of Individual and Organizational Learning Perspectives as Part of IS Analysis," provides a framework for developing a learning organization inclusive of having a constructive dialogue mechanism. The framework, called Strategic Systemic Thinking (SST) is proposed as a means of accessing individual and team competencies for improved systems analysis work. SST provides a means of structuring highly unstructured situations typically found in systems analysis work. It also may be viewed as providing decision-making support for individuals and teams.

Finally, the findings of a research study are presented in an article entitled, "Using the Web to Enable Industry-University Collaboration: An Action Research Study." The authors, Ned Kock, Camille Auspitz, and Brad King, provide the results of their investigation into the use of Web-based collaboration technologies in combination with communication behavior norms and face-to-face meetings. They describe the effect of technologies on the success of a partnership between a large engineering and professional services company and a University.

\section{References}

Allee, V. (1999). The Art and Practice of Being a Revolutionary. Journal of Knowledge Management, 3(2), 121-126.

Argyris, C. (1992). On Organizational Learning. Cambridge, MA: Blackwell Publishers.

Deming, E.W. (1982). Quality, Productivity, and Competitive Position Cambridge, MA: Massachussetts Institute of Technology. New York, NY: John Wiley \& Sons.

Handy, C. (1995). Managing the Dream. S. Chawla \& J. Renesch (Eds), Learning Organizations: Developing Cultures for Tomorrow's Workplace. Portland, OR: Productivity Press, 44-55.

Herbsleb, J. (1994). Benefits of CMM-Based Software Process Improvement: Initial Results (CMU/SEI-94-TR-13, AD-A283848). Pittsburgh, PA: Software Engineering Institute, Carnegie Mellon University.

Larsen, K, B. McInerney, C. Nyquist, A. Santos, and D. Silsbee. (1996). Learning Organizations. PAD633. ed. K. Larsen, http://home.nycap.rr.com/klarsen/learnorg

Paulk, M., B. Curtis, C. Weber, and M. Chrissis . (1995). The Capability Maturity Model: Guidelines for Improving the Software Process. Reading, MA: Addison-Wesley.

Senge, P. M (1990). The Fifth Discipline. New York, NY: Doubleday. 